\author{
Monika Borowiec \\ Zakład Przedsiębiorczości i Gospodarki Przestrzennej \\ Instytut Geografii \\ Akademia Pedagogiczna, Kraków
}

\title{
Rola praktyk z przedsiębiorczości w kształceniu studentów geografii na specjalności „przedsiębiorczość z gospodarką przestrzenną"
}

\begin{abstract}
„W celu podniesienia efektywności transformacji gospodarki narodowej, poprzez racjonalne wdrażanie reguł rynkowych, niezbędnym warunkiem jest przygotowanie społeczeństwa do nowych zachowań, które rozumie mechanizmy współczesnych tendencji procesu rozwoju społeczno-gospodarczego i kulturowego" (Zioło 2004, s. 257). Rozwój przedsiębiorczości jest czynnikiem dynamizującym przeobrażenia strukturalne w okresie transformacji społeczno-gospodarczej (Majecka, Kowalska 2004). Można ją traktować jako stymulator rozwoju społeczno-gospodarczego. A zatem bardzo istotnym w rozwoju przedsiębiorczości jest edukacja i pobudzanie odpowiednich postaw wśród młodych ludzi (Kulikowski, Zielińska 2004). Przede wszystkim powinny być kształtowane postawy konkurencyjnego zachowania na rynku pracy niezależnie od kwalifikacji zawodowych. Raporty edukacyjne postulują zasadniczą zmianę w edukacji nauczycielskiej polegającą na odwróceniu kolejności działań edukacyjnych z kształcenia orientowanego przede wszystkim na wiadomości na kształtowanie osobowości i postaw młodych ludzi oraz wspieranie ich w „poznawaniu świata” i „kierowaniu sobą” (Banach 1996). Jako zasadnicze cechy pożądanej koncepcji edukacji nauczycielskiej, które odpowiadałby na wyzwania cywilizacyjne i edukacyjne jako pierwsze wymienia on otwartość, innowacyjność i perspektywiczność. Zakłada się, że treści kształcenia powinny wynikać nie tylko z rozwoju nauki, ale również z całokształtu zmian i wyzwań związanych z transformacją systemową w Polsce.

W celu doskonalenia systemu kształcenia nauczycieli geografii w Akademii Pedagogicznej im. KEN w Krakowie poszerzono ofertę kształcenia studentów o nowe specjalności m.in. przedsiębiorczość i gospodarkę przestrzenną. Uruchomienie tej specjalności ma na celu podniesienie atrakcyjności studiów geograficznych poprzez przygotowanie nauczycieli do nauczania nowego przedmiotu w szkołach ponadgimnazjalnych, jakim są podstawy przedsiębiorczości, a także rozszerzenie rynku pracy dla naszych absolwentów w zakresie rozwijania działalności gospodarczej, możliwości zatrudnienia $\mathrm{w}$ instytucjach gospodarki przestrzennej i strukturach samorządowych oraz podejmowania pracy $\mathrm{w}$ zakresie organizowania przedsiębiorczości i rozwoju gospodarki na szczeblu gminy, powiatu czy województwa. Na specjalności zmierza się do kształtowania postaw studentów mających sprzyjać zainteresowaniu własnym otoczeniem oraz zaangażowaniu $\mathrm{w}$ poszukiwanie rozwiązań problemów lokalnych i regionalnych zgodnie z Międzynarodową Kartą Edukacji Geograficznej z 1992 r. ogłoszoną przez Komisję Edukacji Geograficznej Międzynarodowej Unii Geograficznej (Hibszer 1996).

Celem kształcenia jej studentów jest zdobycie podstawowych umiejętności w zakresie rozumienia procesów społeczno-gospodarczych oraz funkcjonowania we współczesnym
\end{abstract}


świecie różnej skali podmiotów gospodarczych, analizy i rozumienia podstawowych mechanizmów ekonomicznych we współczesnych systemach zarządzania gospodarką i firmą w zróżnicowanej przestrzeni geograficznej oraz zdobycie umiejętności konkurencyjnego zachowania się na rynku pracy.

Dla realizacji założonych zadań w procesie kształcenia studentów specjalności wprowadzono nowe przedmioty, które znacznie rozszerzają wiedzę ekonomiczną i tworzą nowe i doskonalsze związki między treściami istniejących przedmiotów dając kompleksowy obraz rzeczywistości zgodny z propozycją zarysu koncepcji kształcenia nauczycieli geografii na poziomie akademickim (Turczyn-Zioło, Zioło 1987). Przedmioty specjalnościowe to: elementy prawa gospodarczego i administracyjnego, gospodarka finansowa, polityka ekonomiczna, polityka społeczna, planowanie przestrzenne, zarządzanie edukacją, zarządzanie rozwojem lokalnym i regionalnym, zarządzanie firmą oraz dydaktyka przedsiębiorczości.

Obok wiedzy merytorycznej w tym zakresie bardzo ważne jest kształcenie postaw przedsiębiorczych obejmujących zespół cech osobowych człowieka. Składają się na to postawy takie jak: aktywność, zapał do pracy, inicjatywa, kreatywność, asertywność, innowacyjność, gotowość do podejmowania działalności gospodarczej i ponoszenia związanego z nią ryzyka oraz umiejętności z zakresie komunikacji interpersonalnej, sztuki negocjacji, podejmowania decyzji, kalkulowania nakładów planowanego przedsięwzięcia, wyszukiwania i wykorzystywania szans jakie stwarza rynek oraz stawiania i realizowania postawionych sobie celów poprzez wytyczanie własnej ścieżki kariery zawodowej.

Wyznaczone cele realizowane są w całym cyklu kształcenia studentów na specjalności oraz na praktykach zawodowych prowadzonych na IV roku studiów przez pracowników Zakładu Przedsiębiorczości i Gospodarki Przestrzennej. Praktyki terenowe i zawodowe stanowią $\mathrm{w}$ toku studiów geograficznych jeden $\mathrm{z}$ istotnych elementów procesu dydaktycznego w zakresie różnorodnej problematyki geografii społeczno-ekonomicznej. Umożliwiają one konfrontację teorii $\mathrm{z}$ życiem i nauki $\mathrm{z}$ rzeczywistością, kształtując przez to u studentów umiejętność oceny zjawisk i procesów oraz formułowania wniosków (Pakuła 1967). Jak podkreśla Dobrowolska (1967) metoda obserwacji i analizy terenowej, odgrywająca bardzo ważną rolę $\mathrm{w}$ procesie kształcenia geografa wynika z założeń problematyki geografii ekonomicznej, której przedmiotem jest różnorodność struktur społecznych i ekonomicznych w ich skomplikowanych formach, rozpatrywana z różnych punktów widzenia: ekonomicznego, społecznego, demograficznego i przyrodniczego. „Bezpośredni kontakt z badaną rzeczywistością niezbędny jest zarówno przy rozumowaniu indukcyjnym ze względu na postawienie u progu badań właściwych hipotez, jak też przy rozumowaniu dedukcyjnym, gdy zachodzi konieczność empirycznego sprawdzenia założeń badawczych" (Dobrowolska 1967, s. 9). Ma to bardzo ważne znaczenie bowiem chroni przed zbyt pośpiesznym uogólnianiem zjawisk i procesów.

Praktyki z przedsiębiorczości odbywają się dopiero drugi raz, ale doświadczenie czerpią z szerokiego dorobku metodyki ćwiczeń terenowych z geografii ekonomicznej realizowanych już w byłej Katedrze Geografii Ekonomicznej pod kierunkiem prof. dr hab. M. Dobrowolskiej, dorobku dydaktyków i metodyków w zakresie kształcenia i dokształcania nauczycieli geografii oraz wymiany doświadczeń z innymi ośrodkami akademickimi. Ich problematyka była dyskutowana podczas konferencji naukowych podejmujących zagadnienia związane z przedsiębiorczością.

W niniejszych rozważaniach ograniczę się do zaprezentowania wybranych metod i problematyki badawczej realizowanych praktyk. W toku studiów studenci odbywają 40 godzin praktyk zawodowych pod kierunkiem opiekunów grup, a ich program opracowywany i modyfikowany jest w każdym roku akademickim. Ostatnio praktyki te odbywają się w Krakowie przede wszystkim ze względów ekonomicznych ale zamierzamy w kolejnych edycjach praktyk realizować ich złożoną problematykę poza Krakowem. Z wyborem tematu badawczego wiąże się strona organizacyjna praktyk i podział na grupy. Praca w małych grupach uczy solidarności, współpracy, odpowiedzialności, organizowania pracy zespołowej 
oraz umożliwia rozdzielenie zadań odpowiednio do indywidualnych zdolności (Mądry, Ziętara 1996). Studenci mają do wyboru kilka zróżnicowanych tematów i metod badawczych, co pozwala im na wybór takiej problematyki, która budzi ich największe zainteresowanie i odpowiada ich predyspozycjom psycho-fizycznym.

Postępowanie badawcze obejmuje cztery etapy:

1. etap prac przygotowawczych obejmujący instrukcje badań udzielaną studentom przed rozpoczęciem praktyk, która dotyczy zakresu problematyki i metod badawczych, przygotowanie od strony podstaw teoretycznych, określenie zakresu rzeczowego itp. (Jarowiecka, Górz 1967),

2. badania terenowe obejmujące różne metody badawcze: zbieranie materiałów źródłowych według kwestionariusza, badania ankietowe, metoda obserwacji oraz metoda statystyczno-kartograficzna, badania ankietowe, wywiad,

3. analiza materiałów źródłowych i zebranych informacji, grupowanie statystyczne, opracowanie kartograficzne,

4. prezentacja i ocena wyników badań.

Proponowane zagadnienia wynikają z treści kształcenia na przedmiotach specjalnościowych. Celem ich zatem jest aby studenci zetknęli się z egzemplifikacją empiryczną i kształcili umiejętność analizy wyników. W 2003/2004 roku akademickim program praktyk zawodowych obejmował sześć tematów badawczych dotyczących: funkcjonowania małych podmiotów gospodarczych i dużego przedsiębiorstwa, badań marketingowych związanych z założeniem własnej działalności gospodarczej, funkcjonowania instytucji samorządu terytorialnego w Krakowie, funkcjonowania instytucji pomocy społecznej w Krakowie i form przeciwdziałania bezrobociu oraz działalności instytucji informacyjnych o Unii Europejskiej i wspierających przedsiębiorców i rolników. Problematyka pierwszych trzech tematów badawczych dotyczy funkcjonowania różnego rodzaju firm i analizie rynku. Teoretyczną wiedzę z tego zakresu studenci zdobywają przede wszystkim na II roku studiów na przedmiocie elementy prawa administracyjnego i gospodarczego, na III i IV roku studiów na geografii ekonomicznej i gospodarce finansowej oraz na IV roku na zarządzaniu firmą. Pozostałe tematy obejmujące problematykę dotyczącą różnego rodzaju instytucji społecznogospodarczych bazują przede wszystkim na wiedzy zdobytej przez studentów w ramach polityki gospodarczej na III roku studiów i polityki społecznej na IV roku studiów. Należy zauważyć, że jakkolwiek problematyka związana z funkcjonowaniem Unii Europejskiej jest przedmiotem wielu zajęć $\mathrm{w}$ toku studiów, to przedmiot integracja europejska jest przewidziany na $\mathrm{V}$ roku studiów. A zatem wyniki badań tematu dotyczącego problematyki działalności instytucji informacyjnych o Unii Europejskiej i wspierających przedsiębiorców i rolników powinny zostać zaprezentowane również studentom pozostałych specjalności w ramach przedmiotu integracja europejska.

Pierwszy temat badawczy „Funkcjonowanie małych podmiotów gospodarczych w Krakowie", przeznaczony dla maksymalnie pięciu studentów, oparty jest na analizie 10 przedsiębiorstw osób fizycznych lub spółek cywilnych bądź jawnych o zatrudnieniu od 5-50 osób reprezentujących jeden dział Polskiej Klasyfikacji Działalności. Badania powinny być przeprowadzone w oparciu o kwestionariusz do badań przedsiębiorstw, opracowany na podstawie kwestionariusza T. Rachwała (2001), a wyniki pracy przedstawione w postaci 10 wypełnionych kwestionariuszy oraz analizy funkcjonowania badanych przedsiębiorstw $\mathrm{z}$ uwzględnieniem perspektyw ich rozwoju w Unii Europejskiej.

Drugi temat badawczy dotyczący „Funkcjonowania dużego przedsiębiorstwa” jest przewidziany jako praca indywidualna polegająca na analizie struktury organizacyjnej i kompetencji poszczególnych działów wybranego przedsiębiorstwa zatrudniającego powyżej 250 osób. Praca ta powinna uwzględniać problematykę związaną z zarządzaniem firmą w świetle wywiadów z kierownikami poszczególnych działów, a jej wyniki przedstawione $\mathrm{w}$ formie pisemnej analizy. 
Kolejny temat badawczy „Badania marketingowe związane z założeniem własnej działalności gospodarczej" przeznaczony dla maksymalnie 8 studentów, polega na wyborze i zaplanowaniu rozpoczęcia działalności usługowej na terenie Krakowa. Zadanie to polega na przeprowadzeniu badań ankietowych potencjalnych klientów w oparciu o samodzielne skonstruowaną ankietę oraz analizie konkurencji w oparciu o opracowany kwestionariusz. Zarówno ankieta, jak i kwestionariusz przed rozpoczęciem badań powinny zostać skonsultowane $\mathrm{z}$ opiekunami praktyk. Wyniki badań powinny być przedstawione w postaci pisemnej analizy rynku i konkurencji. Studenci, którzy podjęli ten temat dokonali analizy opłacalności założenia i utrzymania kawiarenki internetowej w Krakowie. Dokonali w tym celu analizy SWOT oraz przeprowadzili badania ankietowe obejmujące 19 pytań kierowanych do potencjalnych klientów kawiarenki internetowej w celu ustalenia preferencji i zapotrzebowania na proponowane usługi. Obejmowały one m.in. pytania dotyczące miejsca, czasu i celu korzystania z Internetu, kosztów związanych korzystaniem z usług „kafejki”, dodatkowych usług w lokalu, a nawet wystroju wnętrza. Dokonali oni również badań konkurencji w oparciu o kwestionariusz obejmujący 10 zagadnień uszczegółowionych w podpunktach dotyczących funkcjonowania tego typu „kafejek”. Wnioski z badań zostały przedstawione w oparciu o analizę statystyczno-kartograficzną uzyskanych odpowiedzi.

Czwarty temat badawczy „Funkcjonowanie instytucji samorządu terytorialnego w Krakowie" przewidziany dla maksymalnie 6 osób, ma na celu zapoznanie się przez studentów z działalnością Urzędu Miasta Krakowa, Starostwa Powiatowego, Urzędu Marszałkowskiego oraz Urzędu Wojewódzkiego w Krakowie. Wyniki pracy powinny być przedstawione $\mathrm{w}$ postaci pisemnej analizy struktur organizacyjnych tych instytucji i zakresu ich kompetencji $\mathrm{w}$ oparciu o rozmowy $\mathrm{z}$ osobami odpowiedzialnymi za funkcjonowanie poszczególnych wydziałów oraz wnioski z własnych obserwacji na temat ich działalności, dostępności i jakości obsługi petentów.

Podobny charakter ma kolejny temat badawczy „Funkcjonowanie pomocy społecznej w Krakowie oraz formy przeciwdziałania bezrobociu", który polega na analizie funkcjonowania instytucji odpowiedzialnych za pomoc społeczną oraz form świadczonej przez nie pomocy. Poza tym studenci w świetle rozmów z pracownikami Grodzkiego Urzędu Pracy mają za zadanie przedstawiać i ocenić formy przeciwdziałania bezrobociu. W opracowanej prezentacji studenci przedstawiają jednostki odpowiedzialne za pomoc społeczną w Krakowie i ich strukturę organizacyjną, tj. Miejski Ośrodek Pomocy Społecznej oraz Wydział Spraw Społecznych Urzędu Miasta Krakowa. Omawiają oni formy pomocy społecznej takie jak praca socjalna, poradnictwo, pożyczki bądź zasiłki celowe, udzielanie schronienia, posiłków, usług opiekuńczych, różne rodzaje pomocy finansowej, rehabilitacji zawodowej i społecznej, orzekanie o stopniu niepełnosprawności, a także warunki jakie muszą spełniać osoby starające się o udzielenie świadczeń pomocy społecznej. Przedstawiają oni funkcje poszczególnych Działów MOPS-u tj.:

- Działu Pomocy Osobom Starszym i Niepełnosprawnym,

- Działu Rehabilitacji Zawodowej i Społecznej Osób Niepełnosprawnych,

- Działu Pomocy Dzieciom,

- Sekcji Planowania i Analiz,

- Działu Programów i Doradztwa w tym Sekcji Pomocy Bezrobotnym,

- Sekcji Kontroli Wewnętrznej,

- Działu Pomocy Bezrobotnym,

- Działu Organizacyjnego,

- Działu Finansowo-Księgowego,

- Działu ds. Dodatków Mieszkaniowych,

- Powiatowego Zespołu do spraw Orzekania o Niepełnosprawności,

- oraz lokalizację Filii MOPS w dzielnicach Krakowa, jak również placówki opiekuńczowychowawcze i domy dziecka nadzorowane przez MOPS. 
Ponadto analiza ta zawiera charakterystykę form zasiłków i dodatków rodzinnych oraz świadczeń opiekuńczych wraz z załącznikami niezbędnych wniosków i oświadczeń, które wypełniają osoby starające się o różne formy pomocy społecznej. W pracy przedstawione są również instytucje zajmujące się zwalczaniem bezrobocia, warunki uzyskania statusu bezrobotnego, rodzaje świadczeń finansowych dla bezrobotnych oraz struktura bezrobotnych w Krakowie według wieku, czasu pozostawania bez pracy, poziomu wykształcenia, stażu pracy. Studenci charakteryzują również programy wspierające bezrobotnych w poszukiwaniu pracy tj. pośrednictwo pracy, poradnictwo zawodowe, klub pracy, szkolenia, pożyczki, prace interwencyjne, roboty publiczne oraz programy specjalne, a także umowy i staże absolwenckie, stypendia, prace społecznie użyteczne, program „Absolwent” oraz programy europejskie („Europejska perspektywa”, „Pozytywny bo aktywny”).

Ostatni zaproponowany temat badawczy „Działalność instytucji informacyjnych o UE i wspierających przedsiębiorców i rolników w zakresie dostosowania ich do funkcjonowania na jednolitym rynku europejskim" przeznaczony jest dla czterech studentów. Wyniki prac powinny być przedstawione $\mathrm{w}$ postaci materiałów informacyjnych uzyskanych $\mathrm{w}$ poszczególnych instytucjach oraz analizie ich dostępności i zakresu działalności. Studenci przedstawiają również zasady funkcjonowania Jednolitego Rynku Europejskiego (JRE), rodzaje spółek w UE tj. Europejskiego Zgrupowania Interesów Gospodarczych oraz Europejskiej Spółki Akcyjnej oraz kryteria przynależności do sektora małych i średnich przedsiębiorstw, a także programy wsparcia dla tego sektora. Przedstawiane są projekty wspierane przez Sektorowy Program Operacyjny Wzrost Konkurencyjności Przedsiębiorstw finansowany z Środków Europejskiego Funduszu Rozwoju Regionalnego na wsparcie instytucji otoczenia przedsiębiorczości w ramach Priorytetu 1: Rozwój przedsiębiorczości i wzrost innowacyjności z wykorzystaniem instytucji otoczenia biznesu oraz Dotacje dla przedsiębiorstw w ramach Priorytetu 2: Wzmocnienia pozycji konkurencyjnej przedsiębiorstw działajacych na JRE. Ponadto przedstawiaja ona programy wspierajace rolników $w$ UE.

Etapy realizacji badań terenowych są sprawdzane i dyskutowane podczas zaplanowanych spotkań grup badawczych z opiekunami praktyk, które mają charakter naprowadzający i korygujący, tak aby praca studentów była jak najbardziej samodzielna i mogli się oni wykazać własną inicjatywą. Wyniki wszystkich prac są przedstawiane na zebraniu podsumowującym praktyki zawodowe, zazwyczaj w formie prezentacji multimedialnej, co umożliwia zapoznanie się i przedyskutowanie całości problematyki wszystkim studentom. Jest to również bardzo istotne dla kształtowania postawy otwartości w stosunku do grupy oraz konkurencyjności przejawiającej się jako dbanie o jak najwyższą jakość wystąpienia i poziom merytoryczny prezentowanych wyników pracy, które zostają poddane ocenie nie tylko opiekunów praktyk ale także pozostałych studentów. Forma taka ma na celu również przełamywanie obaw związanych z wystąpieniami publicznymi, które wydają się być bardzo istotnym czynnikiem niechęci $\mathrm{w}$ podejmowaniu aktywności w życiu społeczno-gospodarczym, niejednokrotnie utrudniającym wykonywanie zawodu lub obniżającym jakość pracy. Staramy się również kształtować u studentów umiejętność oceny analizowanych przez siebie i prezentowanych przez innych zagadnień, doboru najistotniejszych treści oraz jak najlepszej ich prezentacji w celu zaciekawienia i poszerzenia wiedzy pozostałych osób. Jest to szczególnie istotne biorąc pod uwagę profil kształcenia Akademii Pedagogicznej.

Podsumowując praktyki odbyte w 2004 r. wydaje się, że spełniły one zakładane założenia. Studenci z zaangażowaniem realizowali tematy badawcze wykazując dużo własnej inicjatywy i samodzielności w badaniach terenowych. Wydaje się, że proponowane zagadnienia wzbudziły ich zainteresowanie i wszystkie grupy dokonały właściwej i wyczerpującej analizy podjętych tematów. W trakcie prezentacji opiekunowie starali się zwracać uwagę i odwoływać do zagadnień, które były przedmiotem ćwiczeń, a teraz zostały pogłębione $\mathrm{w}$ analizie i przedstawione od strony praktycznej. Umożliwiło to studentom przypomnienie i lepsze opanowanie realizowanej w toku studiów problematyki. Prezentacje multimedialne 
przygotowane przez studentów i dyskusja podsumowująca praktyki znacznie wzbogaciły wiedzę uczestników i otwarły nowe pola badawcze.

Wydaje się jednak, że nadal pewną trudność sprawia studentom formułowanie własnych ocen i uogólnianie wyników badań, jak również zauważa się, że niewielu studentów chętnie podejmuje się prezentacji przed grupą, mimo nawet wcześniejszego skonsultowania pracy i wystąpienia z opiekunami praktyk. Można zatem stwierdzić, że większym stopniu w toku studiów powinien być kładziony nacisk na kształtowanie postawy otwartości, śmiałości i własnej inicjatywy. Powinno to być realizowane na wszystkich zajęciach, nie tylko na poziomie szkoły wyższej m.in. poprzez zachęcanie młodzieży do podejmowania dyskusji, stwarzanie możliwości wyrażania własnych opinii i kształtowania umiejętności formułowania wniosków oraz zachęcania do postawy konkurencyjnej już na etapie kształcenia w szkole i na studiach.

Wydaje się, różnorodność tematów badawczych podejmowanych podczas praktyk zawodowych umożliwiła studentom zapoznanie się z szeregiem zagadnień społecznoekonomicznych związanych z naukowymi i dydaktycznymi założeniami kształcenia nauczycieli na specjalności.

Sądzimy, że forma i tematyka praktyk zawodowych poza zdobyciem wiedzy merytorycznej, praktycznych informacji dotyczących funkcjonowania różnego rodzaju firm i instytucji, umiejętności $\mathrm{w}$ zakresie analizy zjawisk i procesów społeczno-gospodarczych oraz właściwej prezentacji wniosków i formułowania własnych ocen umożliwia również kształcenie postaw przedsiębiorczych.

\section{LITERATURA}

Banach Cz., 1996, Koncepcja edukacji nauczycielskiej $w$ świetle badań pedeutologicznych,(red. Jarowiecki J., Piskorz S.) [w:] Różne drogi kształcenia i dokształcania nauczycieli, Centralny Ośrodek Metodyczny Studiów Nauczycielskich przy Wyższej Szkole Pedagogicznej im. Komisji Edukacji Narodowej, Kraków.

Dobrowolska M., 1967, Struktura regionu i powiazań regionalnych (Problematyka i metody badań terenowych), [w:] Wybrane zagadnienia $\mathrm{z}$ metodyki ćwiczeń terenowych $\mathrm{z}$ geografii ekonomicznej, J. Jarowiecki (red.), Prace z Dydaktyki Szkoły Wyższej, z. 4, Wydawnictwo Naukowe Wyższej Szkoły Pedagogicznej im. Komisji Edukacji Narodowej, Kraków.

Jarowiecka T., Górz B., 1967, Rola instytucji i organizacji w kształtowaniu powiazań osadniczych (Ćwiczenia terenowe z geografii gospodarczej) [w:] Wybrane zagadnienia z metodyki ćwiczeń terenowych z geografii ekonomicznej, J. Jarowiecki (red.), Prace z Dydaktyki Szkoły Wyższej, z. 4, Wydawnictwo Naukowe Wyższej Szkoły Pedagogicznej im. Komisji Edukacji Narodowej, Kraków.

Hibszer A., 1996, Ksztaltowanie $i$ wychowanie regionalne $w$ programie geograficznych studiów nauczycielskich, [w:] Różne drogi kształcenia i dokształcania nauczycieli, J. Jarowiecki, S. Piskorz (red.), Centralny Ośrodek Metodyczny Studiów Nauczycielskich przy Wyższej Szkole Pedagogicznej im. Komisji Edukacji Narodowej, Kraków.

Kulikowski M., Zielińska M., 2004, Promowanie postaw przedsiębiorczych na poziomie podstawowym i średnim w Europie [w:] Przedsiębiorczość jako stymulator rozwoju regionalnego, J. Brdulak, M. Kulikowski (red.), Instytut Wiedzy Szkoła Główna Handlowa, Warszawa.

Majecka B., Kowalska I., 2004, Podstawy przedsiębiorczości w szkole - dodatkowe obciązenie ucznia czy konieczność ? [w:] Przedsiębiorczość jako stymulator rozwoju regionalnego, J. Brdulak, M. Kulikowski (red.), Instytut Wiedzy Szkoła Główna Handlowa, Warszawa. 
Mądry J., Ziętara T., 1996, Ksztatcenia nauczycieli geografii poprzez przedmiotowe i regionalne ćwiczenia terenowe,[w:] Różne drogi kształcenia i dokształcania nauczycieli, J. Jarowiecki, S. Piskorz (red.), Centralny Ośrodek Metodyczny Studiów Nauczycielskich przy Wyższej Szkole Pedagogicznej im. Komisji Edukacji Narodowej, Kraków.

Pakuła L., 1967, Uwagi metodyczne o prowadzeniu ćwiczeń terenowych z geografii przemystu [w:] Wybrane zagadnienia z metodyki ćwiczeń terenowych z geografii ekonomicznej, J. Jarowiecki (red.), Prace z Dydaktyki Szkoły Wyższej, z. 4, Wydawnictwo Naukowe Wyższej Szkoły Pedagogicznej im. Komisji Edukacji Narodowej, Kraków.

Rachwał T., 2001, Problematyka kwestionariusza do badań funkcjonowania przedsiębiorstwa przemystowego w okresie transformacji systemu gospodarowania, [w:] Problemy przemian struktur przestrzennych przemysłu, red. Z. Zioło, Prace Komisji Geografii Przemysłu PTG nr 2, Warszawa-Kraków.

Turczyn-Zioło I., Zioło Z., 1987, Zarys koncepcji zintegrowanego kształcenia nauczycieli geografii, [w:] Ćwiczenia na studiach geograficznych, S. Zając, Z. Zioło (red.), Problemy Studiów Nauczycielskich, z. 3, Wydawnictwo Naukowe Wyższej Szkoły Pedagogicznej im. Komisji Edukacji Narodowej, Kraków.

Zioło Z., 2004, Problematyka ksztatcenia nauczycieli do nauczania „Przedsiębiorczości” w Akademii Pedagogicznej im. Komisji Edukacji Narodowej [w:] Przedsiębiorczość jako stymulator rozwoju regionalnego J. Brdulak, M. Kulikowski (red.), Instytut Wiedzy Szkoła Główna Handlowa, Warszawa. 